\title{
UPAYA MENINGKATKAN PRESTASI BELAJAR PAI MATERI AKHLAK TERPUJI MELALUI PENERAPAN MODEL PEMBELAJARAN READING GUIDE PADA SISWA KELAS 4 DI SD O02 BELAKANG PADANG
}

\author{
JUMIAH \\ SDN 002 Belakang Padang Kota Batam \\ jumiahwir@gmail.com
}

\begin{abstract}
ABSTRAK
Penelitian ini bertujuan untuk meningkatkan prestasi belajar PAI materi akhlak terpuji dengan menggunakan model pembelajaran Reading Guide pada siswa kelas 4 SD Negeri 002 Belakang Padang Tahun 2015/2016. Subyek penelitian sebanyak 15 orang, terdiri dari 8 siswa perempuan dan 7 siswa laki-laki. Penelitian ini dilaksanakan pada 12 sampai 28 Februari 2015. Penelitian ini merupakan Penelitian Tindakan Kelas yang terdiridari 2 siklus yang masing-masing siklus terdiri dari 4 tahap yaitu perencanaan, pelaksanaan, pengamatan, dan refleksi. Metode pengumpulan data yang digunakan yaitu tes tertulis dan dokumentasi. Analisis data pada penelitian ini yaitu dengan membandingkan pencapaian nilai dengan KKM dan ditandai dengan adanya peningkatan Kriteria Ketuntasan Klasikal pada setiap siklusnya.

Hasil penelitian pada siklus I dan siklus II diperoleh data seperti berikut: KKM mata pelajaran Pendidikan Agama Islam adalah 70, sebelum menggunakan model pembelajaran reading guide hanya ada $40 \%$ (6 siswa) yang tuntas, sedangkan 60\% (9 siswa) belum memenuhi KKM. Setelah penggunaan model pembelajaran reading guide dalam pelajaran PAI pada siklus I diperoleh data $73 \%$ (11 siswa) tuntasdan $27 \%$ (4 siswa) tidak tuntas, sehingga terjadi peningkatan sebesar $33 \%$ dibandingkan pada pra siklus. Setelah itu dilakukan refleksi siklus I, terjadi peningkatan prestasi belajar pada siklus II yaitu sebesar 93\% (14 siswa) tuntas dan 27\% (4 siswa) belum memenuhi KKM. Dengan demikian dari siklus I ke siklus II terjadi peningkatan prestasi belajar sebesar $20 \%$. Prosentase Kriteria Ketuntasan Klasikal pada siklus II ini mencapai 93\% dengan nilai rata-rata 75.33 .

Dengan kata lain sudah memenuhi indicator keberhasilan yang ditentukan yaitu prosentase Kriteria Ketuntasan Klasikal sebesar 85\% dengan standar KKM 70.
\end{abstract}

Kata kunci : Prestasi Belajar PAI, Model Pembelajaran Reading Guide

\section{PENDAHULUAN}

Pendidikan Agama Islam merupakan bagian yang tak terpisahkan dari sistem pendidikan di Indonesia, sebagaimana yang tercantum dalam Undang-undang Nomor 20 tahun 2003 tentang Sistem Pendidikan Nasional pasal 12 ayat 1 butir a yang menyatakan bahwa "Setiap peserta didik pada setiap satuan pendidikan berhak mendapatkan pendidikan agama sesuai dengan agama yang dianutnya dan diajarkan oleh pendidik yang seagama" (UU No 20/2003, Sisdiknas:9). Dengan kata lain, apabila 
dalam satuan lembaga pendidikan ada peserta didik yang beragama Islam maka mereka berhak mendapatkan pendidikan agama Islam dan diajarkan oleh guru yang beragama Islam. Islam dengan tegas telah mewajibkan agar umatnya melakukan pendidikan,

Sasaran Pendidikan Agama Islam tertuju pada pembentukan sikap, akhlak atau mental anak didik dalam hubungannya dengan Tuhan, masyarakat dan alam atau sesama makhluk. Anak adalah cerminan masa depan, pendidikan anak harus benarbenar diperhatikan agar bakat mereka tersalurkan dalam kegiatan yang positif, yaitu di antaranya dengan memasukkan anak ke dalam jenjang pendidikan yang formal ataupun yang non formal. Penanaman nilai agama Islam kepada mereka merupakan syarat mutlak untuk mencapai nilai keharmonisan dalam menjalani kehidupan dunia dan akhirat.

Nilai-nilai tersebut dapat dijadikan pondasi agar mereka tidak keluar dari ajaran-ajaran agama. Dalam pembelajaran Pendidikan Agama tidaklah mudah, jika dilihat sekilas materi yang disampaikan terlihat mudah untuk dipahami, akan tetapi fakta yang ditemukan bahwa siswa mengalami kesulitan dalam belajar Pendidikan Agama Islam, bahkan ada siswa yang sampai malas untuk mengikuti pelajaran Agama Islam, ini dikarenakan kurang termotivasinya siswa dalam mengikuti pelajaran Pendidikan Agama Islam tersebut.

Dengan demikian dalam pembelajaran Agama di tingkat Sekolah Dasar perlu adanya modifikasi dalam penyampaian materi. Penggunaaan strategi belajar yang tepat diharapkan dapat memotivasi siswa dalam pembelajaran. Ketika siswa sudah termotivasi secara otomatis prestasi/hasil belajar mereka juga akan menjadi lebih baik dan mampu mencapai KKM. Prinsip utama dari proses pembelajaran adalah adanya proses keterlibatan seluruh atau sebagian potensi siswa dan kebermaknaannya bagi diri sendiri dan kehidupannya saat ini dan masa mendatang (Kusnandar, 2011:293). Menurut Kusnandar (2011:329) bahwa melibatkan siswa secara aktif dalam pembelajaran dan menggunakan cara atau metode dan media mengajar yang bervariasi diyakini dapat membangkitkan motivasi belajar siswa, sehingga akan membantu peningkatan prestasi belajar.

Dari pendapat di atas dapat ditarik kesimpulan bahwa penggunaan metode, strategi, dan media pembelajaran sangat diperlukan untuk meningkatkan pemahaman dan prestasi/hasil belajar siswa. Berdasarkan pengalaman peneliti sekaligus guru PAI di SD Negeri 002 Belakang Padang diperoleh prestasi belajar siswa pada mata pelajaran Pendidikan Agama Islam masih rendah. Rendahnya hasil belajar ini ditandai dengan masih banyaknya siswa yang belum mencapai KKM. Dari seluruh siswa yang berjumlah 15 siswa, hanya 6 siswa yang sudah mencapai KKM. Pada penelitian ini, nilai Ketuntasan PAI yaitu 70 dengan tingkat ketuntasan klasikal sebesar $85 \%$. Dengan demikian, diperlukan langkah solutif untuk memecahkan permasalahan tersebut. Disini guru dituntut untuk lebih kreatif dan inovatif dalam mengemas suatu materi pembelajaran. Bahkan jika diperlukan guru mengadakan atau membuat alat peraga atau media untuk memperjelas penyampaian materi yang akan disampaikan di kelas.

Berdasarkan telaah guru dan peneliti untuk meningkatkan hasil belajar Pendidikan Agama Islam materi perilaku akhlak terpuji, peneliti mencoba mencari satu solusi dalam pembelajaran yang nantinya akan mengatasi kesulitan belajar, yaitu dengan menggunakan model yang lebih menyenangkan dan siswa dituntut aktif dalam 
proses KBM. Banyak model ditemukan guna mengoptimalkan hasil belajar, salah satunya adalah model pembelajaran reading guide. Model pembelajaran reading guide diharapkan dapat menciptakan pembelajaran yang kondusif dan memudahkan peserta didik untuk fokus dalam memahami pelajaran yang disampaikan oleh guru. Model pembelajaran reading guide akan membantu siswa untuk menghilangkan sifat malas membaca, karena metode ini menuntun siswa untuk membaca materi yang diberikan. Melalui langkah setiap peserta didik mendapatkan bacaan, yang mana bacaan tersebut membimbing jawaban pertanyaan atau kisi-kisi yang ada maka peserta didik akan lebih terfokus dalam memahami pelajaran.

Dengan menuntun dan mengarahkan bahan bacaan, diharapkan akan merangsang daya ingat dan konsentrasi peserta didik terhadap pelajaran yang disampaikan. Berdasarkan permasalahan tersebut, peneliti bermaksud melakukan penelitian tindakan kelas dengan judul "Upaya Meningkatkan Prestasi Belajar PAI Materi Akhlak Terpuji Melalui Penerapan Model Pembelajaran Reading Guide Pada Siswa Kelas 4 di SD Negeri 002 Belakang Padang “

\section{METODE PENELITIAN}

Penelitian ini menggunakan model penelitian tindakan (action research). Sesuatu tindakan yang secara khusus diamati terus-menerus, dilihat plus-minusnya, kemudian diadakan pengubahan terkontrol sampai pada upaya maksimal dalam bentuk tindakan yang paling tepat (Arikunto, 2007:2). Sementara itu, menurut Suyanto dalam Basrowi dan Suwandi (2008:26) Penelitian tindakan kelas adalah suatu bentuk penelitian yang bersifat reflektif dengan melakukan tindakan-tindakan tertentu agar dapat memperbaiki dan atau meningkatkan praktik-praktik pembelajaran di kelas secara lebih professional. Penelitian tindakan juga digambarkan sebagai suatu proses yang dinamis di mana empat aspek, yaitu perencanaan, tindakan, observasi, dan refleksi harus dipahami bukan sebagai langkah-langkah yang statis, terselesaikan dengan sendirinya, tetapi lebih merupakan momen-momen dalam bentuk spiral yang menyangkut perencanaan, tindakan, pengamatan, dan refleksi (Kemmis \& McTaggart dalam Basrowi dan Suwandi, 2008:26)

Subjek penelitian adalah siswa kelas 4 SD Negeri 002 Belakang Padan Tahun Ajaran 2020/2021 yang berjumlah 15 orang siswa terdiri dari 7 putra dan 8 putri. Penelitian ini dilaksanakan dengan 2 Siklus dengan jadwal yang sudah ditentukan

Penelitian tindakan kelas dimulai dengan siklus pertama yang terdiri dari empat kegiatan, yakni perencanaan, tindakan, observasi dan refleksi. Berdasarkan siklus pertama tadi, guru akan mengetahui letak keberhasilan dan kegagalan atau hambatan yang dijumpai pada siklus pertama tersebut. Oleh karena itu, guru merumuskan kembali rancangan tindakan untuk siklus kedua. Kegiatan pada siklus kedua ini dapat berupa kegiatan sebagaimana yang dilakukan pada siklus pertama, tapi sudah dilakukan perbaikan-perbaikan atau tambahan-tambahan berdasarkan hambatan atau kegagalan yang dijumpai pada siklus pertama. Instrumen Penelitian berupa. tes tertulis, pedoman dokumentas, pengumpulan data

Pengumpulan data dilakukan Tes Tertulis, Dokumentasi dan Analisis Data. Dalam penelitian ini, penulis menganalisis dengan cara a. Membandingkan Pencapaian Nilai 
dengan Kriteria Ketuntasan Minimal (KKM) b. Pencapaian Kriteria Ketuntasan Klasikal

Menurut Depdikbud (dalam Trianto, 2009:241) setiap siswa dikatakan tuntas belajarnya (ketuntasan individu) jika proporsi jawaban benar siswa $\geq 65 \%$ dan suatu kelas dikatakan tuntas belajarnya (ketuntasan klasikal) jika dalam kelas tersebut terdapat $\geq 85 \%$ siswa yang telah tuntas belajarnya. Tetapi berdasarkan ketentuan KTSP penentuan ketuntasan belajar ditentukan sendiri oleh masingmasing sekolah yang dikenal dengan istilah kriteria ketuntasan minimal, dengan berpedoman pada tiga pertimbangan, yaitu: kemampuan peserta didik berbeda-beda; fasilitas (sarana) setiap sekolah berbeda.

Berdasarkan penjelasan tersebut, maka keberhasilan penelitian ini dapat dilihat dari prestasi belajar siswa, yaitu apabila siswa telah mencapai criteria ketuntasan klasikal 85\% dari jumlah seluruh siswa dengan nilai KKM 70. Untuk mengetahui peningkatan prestasi belajar peserta didik, peneliti menggunakan statistik deskriptif dengan mencari prosentase dari hasil belajar peserta didik, sebagaimana rumus :(Aqib, dkk., 2009:40)

\section{HASIL DAN PEMBAHASAN}

\section{Deskripsi Awal (Pra Siklus)}

1. Perolehan Nilai Ulangan Harian Mata Pelajaran PAI

Pada tahap ini peneliti menggunakan nilai ulangan harian mata pelajaran PAI untuk memperoleh kemampuan siswa kelas IV SD Negeri 002 Belakang Padang. Berikut ini hasil nilai ulangan harian sebelum diberikan tindakan berupa model pembelajaran reading guide.

\begin{tabular}{|l|l|}
\hline \multicolumn{1}{|c|}{ Indikator } & \multicolumn{1}{c|}{ Pra Siklus } \\
\hline Banyak pesertta didik memperoleh nilai $\geq 70$ & 6 \\
\hline Banyak pesertta didik memperoleh nilai $<70$ & 9 \\
\hline Nilai Rata rata & 60,26 \\
\hline Ketuntasan Belajar & $40 \%$ \\
\hline
\end{tabular}

\section{Data Keadaan Siswa}

Penelitian ini dilakukan di ruang kelas IV di SD Negeri 002 Belakang Padang. Sedangkan subjek penelitian tersebut adalah seluruh anak kelas IV di SD Negeri 002 Belakang Padang yang berjumlah 15 anak yang terdiri dari 7 laki-laki dan 8 perempuan. Adapun data selengkapnya sebagai berikut:

Penelitian ini dilaksanakan pada mata pelajaran Pendidikan Agama Islam materi akhlak terpuji. Penelitian ini menggunakan model pembelajaran Reading Guide yang dilaksanakan sebanyak 2 siklus. 


\section{Deskripsi Pelaksanaan Siklus I}

Pada siklus I, hasil pengamatan dan refleksi menunjukkan siswa dalam kategori kurang paham sudah berkurang jika dibandingkan dengan pra Siklus. Selain itu bimbingan guru terhadap siswa serta motivasi yang diberikan cukup membuat anak mengerti pentingnya materi pendidikan. Dari prestasi belajar siswa juga terjadi peningkatan kemampuan siswa dalam menyelesaikan tugas dengan baik. Terbukti dari tingkat ketuntasan belajar klasikal pra siklus sebesar $40 \%$ dengan nilai rata-rata 60.26 , pada siklus I menjadi $73.33 \%$ dengan nilai rata-rata 70.67 . Dengan demikian dapat disimpulkan terdapat peningkatan kemampuan siswa dalam hasil belajar siswa. Setelah melaksanakan tindakan pengamatan dalam pembelajaran di dalam kelas, selanjutnya diadakan refleksi dari tindakan yang dilakukan. Data-data yang diperoleh dari observasi dikumpulkan, dianalisis dan digunakan sebagai dasar untuk membuat perencanaan pembelajaran siklus II.

\section{Deskripsi Pelaksanaan Siklus II}

Dalam kegiatan pada siklus II didapatkan, sebagai berikut:

a. Proses belajar mengajar dengan metode reading guide ini berjalan lancar, semua siswa telah memahami dan berjalan sendiri tanpa harus diperintah oleh guru.

b. Suasana kelas dalam pembelajaran sudah aktif, sebagian besar siswa sudah memperhatikan dengan baik. Suasana kelas terlihat kondusif sebagaimana proses belajar mengajar pada umumnya.

c. Pelaksanaan siklus II berlangsung dengan baik, kondusif, serta aktivitas belajar siswa meningkat.

Sedangkan hasil belajar siswa telah mencapai nilai rata-rata 75.33 sehingga meningkat lebih baik dari siklus sebelumnya. Tingkat ketuntasan klasikal sudah memenuhi indikator keberhasilan $85 \%$ dengan prosentase mencapai $85 \%$. Dengan demikian, dapat dikatakan pelaksanaan siklus II ini berhasil, karena ada peningkatan kemampuan siswa dalam menyelesaikan tugas dengan baik. Hal ini terbukti dari daya serap yang dicapai berturut-turut, sehingga peneliti dapat mengatakan siklus II telah berhasil dengan baik.

\section{Deskripsi Hasil Penelitian}

Pada penelitian ini, peneliti melaksanakan Penelitian tindakan kelas (PTK) dengan menggunakan model pembelajaran reading guide. Model pembelajaran reading guide bukanlah model pembelajaran baru di dunia pendidikan Indonesia, namun model pembelajaran yang baru bagi SD Negeri 002 Belakang Padang Acuan penilaian pada penelitian ini, peneliti menggunakan Kriteria ketuntasan Klasikal 85\% dari jumlah sluruh siswa yang berpatokan pada nilai Kriteria Ketuntasan Minimal (KKM). Berdasarkan data nilai ulangan harian mata pelajaran PAI diperoleh kelas IV SD Negeri 002 Belakang Padang menunjukkan bahwa KKM untuk mata pelajaran PAI adalah 70. 


\section{PEMBAHASAN}

Penelitian tindakan kelas ini dilakukan dalam 2 siklus, dari data yang diperoleh menunjukkan bahwa terjadi peningkatan nilai siswa yang cukup baik. Selain itu ansias siswa dalam mengikuti proses pembelajaran juga sangat tinggi. Dengan demikian, apabila dipadukan dengan menggunakan model pembelajaran reading guide dalam pembelajaran PAI dapat meningkatkan prestasi belajar siswa kelas IV SD Negeri 002 Belakang Padang. Hal ini dapat dilihat tabel gabungan nilai evaluasi dari siklus ke siklus sebagai berikut :

Berdasarkan pada tabel tersebut dapat diketahui bahwa perolehan rata-rata nilai pada siklus I meningkat dibandingkan pada pra siklus, yaitu dari 60.26 menjadi 70.67. Pada siklus II juga mengalami peningkatan secara signifikan yaitu dengan nilai rata-rata mencapai 75.33 dari siklus sebelumnya 70.67. Berdasarkan data tersebut, maka dapat diketahui bahwa pelaksanaan PTK dengan menggunakan model pembelajaran reading guide berhasil meningkatkan prestasi belajar siswa.

Berikut penjabaran dari hasil penelitian dari siklus ke siklus:

1. Siklus I

Proses pembelajaran pada siklus I, peneliti menggunakan model pembelajaran reading guide. Adapun dalam penelitian mencakup 4 tahap yaitu tahap perencanaan, pelaksanaan, pengamatan, dan refleksi. Sebelum dilakukan penelitian, peneliti melakukan observasi ke SD Negeri 002 Belakang Padang. Pada tahap ini hasil tes evaluasi siklus I adalah $73 \%$ siswa tuntas (11 siswa) dan yang tidak tuntas $27 \%$ (4 siswa). Dengan demikian siklus I mengalami peningkatan dibanding pra siklus sebesar $33 \%$. Untuk perolehan hasil tes evaluasi pada siklus satu dapat dilihat di bawah ini:

Fresenthe kni Tes Evolunat Sikhs I

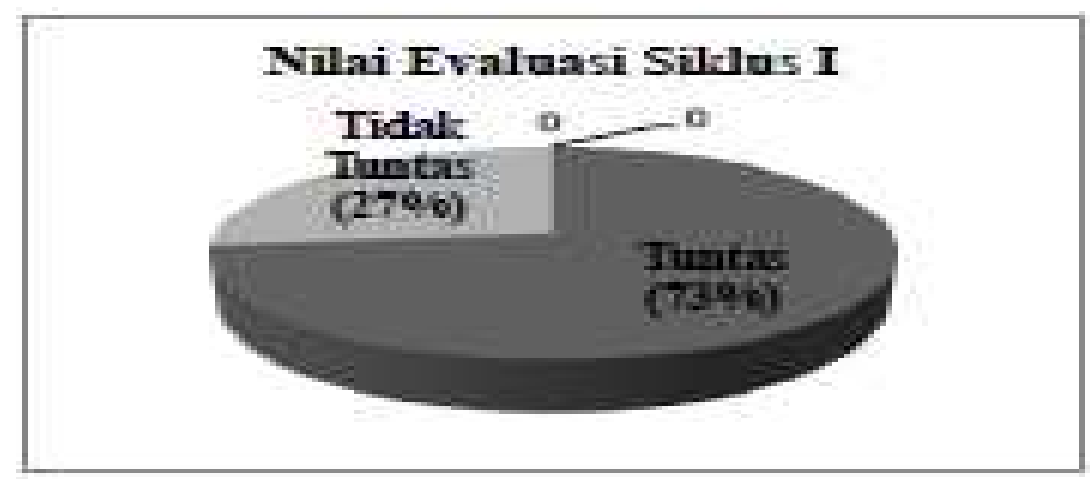

Hasil pengamatan yang dilakukan oleh mitra peneliti pada siklus II adalah sebagai berikut:

a. Kehadiran Siswa

Pada siklus I yang dilaksanakan 100\% dari seluruh siswa kelas IV SD Negeri 002 Belakang Padang dapat hadir di kelas.

b. Pemahaman siswa terhadap Materi

Pada siklus I, 73\% (11 siswa) telah memahami materi yang disampaikan guru, sedangkan $27 \%$ (4 siswa) kurang memahami materi. Terdapat 4 siswa yang tidak 
tuntas, nilai yang mereka peroleh belum mencapai KKM yang ditentukan oleh sekolah yaitu 70. Dengan demikian, pada siklus I belum memenuhi indicator keberhasilan sebesar $85 \%$, sehingga diperlukan langkah selanjutnya melalui siklus 2 .

2. Siklus II

Pada siklus II tindakan penelitian mempertimbangkan kekurangan dan kendala yang muncul pada siklus I. Untuk proses pembelajaran masih sama dengan siklus I yaitu dengan menggunakan model pembelajaran reading guide. Pada siklus II ini persentase ketuntasan klasikal siswa meningkat sebesar 20\%. Dari siklus sebelumnya sebesar $73 \%$ menjadi $93 \%$ siswa tuntas. Dari data ini, diperoleh data siswa yang tidak tuntas sebesar $7 \%$. Dengan demikian, presentase nilai yang diperoleh pada siklus II telah memenuhi indikator keberhasilan dengan tingkat ketuntasan sebesar 85\% siswa mencapai KKM. Perolehan presentase nilai tes evaluasi pada siklus II sebagai berikut:

Dresentase Nilai Tes Evaluasi Sikhe II

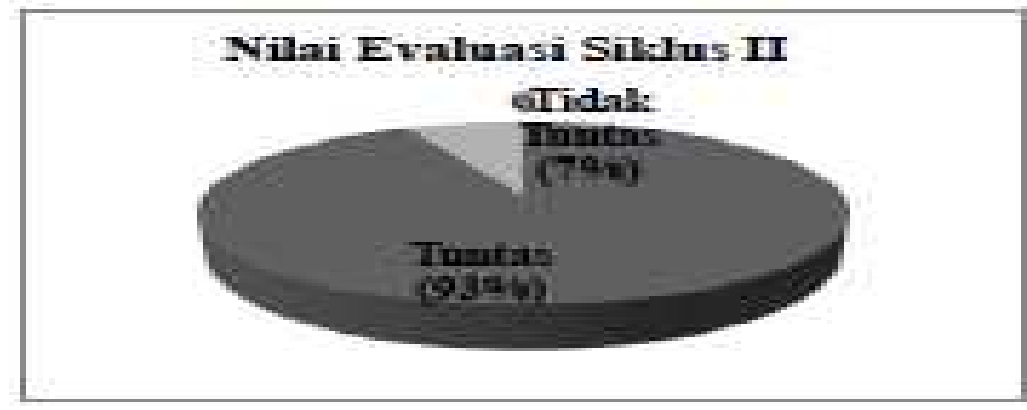

Hasil pengamatan yang dilakukan oleh mitra peneliti pada siklus II adalah sebagai berikut:

a. Kehadiran Siswa

Pada siklus II yang dilaksanakan pada tanggal 26 Februari 2015, 100\% dari seluruh siswa kelas IV SD Negeri 002 Belakang Padang dapat hadir di kelas.

b. Pemahaman Siswa terhadap Materi

Pada siklus II, 93\% (14 siswa) telah memahami materi yang disampaikan guru, sedangkan 7\% (1 siswa) kurang memahami materi.. Dengan demikian, pada siklus II sudah memenuhi indicator keberhasilan sebesar $85 \%$.

3. Rekapitulasi Ketuntasan Gabungan

Rekapitulasi Ketuntasan Gabungan

\begin{tabular}{|c|c|c|c|c|c|c|c|}
\hline \multirow{2}{*}{ NO } & \multirow{2}{*}{ Kategori } & \multicolumn{2}{|c|}{ Pra Siklus } & \multicolumn{2}{c|}{ Siklis I } & \multicolumn{2}{c|}{ Siklis II } \\
\cline { 3 - 8 } & & Frekwensi & $\%$ & Frekwensi & $\%$ & Frekwensi & $\%$ \\
\hline 1 & Tuntas & & & & & & \\
\hline 2 & $\begin{array}{c}\text { Tidak } \\
\text { tuntas }\end{array}$ & 9 & $60 \%$ & 4 & $27 \%$ & 1 & $7 \%$ \\
\hline \multicolumn{2}{|c|}{ Jumlah } & 15 & $100 \%$ & 15 & $100 \%$ & 15 & $100 \%$ \\
\hline
\end{tabular}


Berdasarkan tabel tersebut, dapat diketahui bahwa ketuntasan siswa kelas IV SD Negeri 002 Belakang Padang meningkat. Dari pra siklus, presentase ketuntasan klasikal sebesar $40 \%$ menjadi $73 \%$ pada siklus I. kemudian meningkat lagi pada siklus II sebesar 93\%. Dan pada siklus II meningkat sebesar $20 \%$ dengan presentase ketuntasan klasikal mencapai 93\%. Artinya pada siklus II sudah mencapai indikator keberhasilan dengan presentase yang ditentukan $85 \%$.

\section{KESIMPULAN}

Berdasarkan hasil penelitian, dapat disimpulkan bahwa penerapan model pembelajaran reading guide dapat meningkatkan prestasi belajar PAI materi akhlak terpuji di kelas IV SD Negeri 002 Belakang Padang. Siswa mencapai KKM ditandai dengan peningkatan Kriteria Ketuntasan Klasikal pada siklus 1 sebesar $73 \%$ dan siklus II sebesar 93\%.Disarankan kepada giru sebaiknya lebih variatif dalam menggunakan strategi pembelajaran, termasuk menggunakan metode reading guide. Hal ini akan menghilangkan kebosanan dari para siswa dalam mengikuti proses belajar mengajar, para guru hendaknya tidak takut-takut dalam mencoba strategi baru dalam pembelajaran untuk meningkatkan motivasi belajar anak serta meningkatkan hasil pembelajaran. Sebelum melaksanakan strategi pembelajaran jenis baru, hendaknya guru melakukan persiapan sebaik-baiknya dengan mempertimbangkan materi yang sesuai.dan Pihak sekolah diharapkan memberikan dukungan serta himbauan kepada para guru untuk lebih kreatif dalam menyampaikan materi pelajaran di kelas., melengkapi sarana dan prasarana yang menunjang bagi penerapan strategi pengajaran yang lebih baik.

\section{DAFTAR PUSTAKA}

Muhaimin, dkk..2004.Paradigma Pendidikan Islam Upaya Mengefektifkan Pendidikan Agama Islam di Sekolah. Bandung: Remaja Rosdakarya

Nizar, Samsul, 2002, Filsafat Pendidikan Islam, pendekatan Historis, Teoritis dan Praktis, cet. ke-1, Jakarta: Ciputat Pers.

Abdurrahman, Mulyono. 1999. Pendidikan Bagi Anak Berkesulitan Belajar. Jakarta: Rineka Cipta

Thohirin.2008. Psikologi Pembelajaran Pendidikan Agama Islam. Jakarta: PT Raja Grafindo Persada

Trianto.2009. Mendesain Model Pembelajaran Inovatif-Progresif. Jakarta: Kencana Prenada Media

Aqib, Zainal, dkk.2009. Penelitian Tindakan Kelas Untuk SD, SLB, dan TK, Bandung:Rama Widya

Arikunto, Suharsimi dkk.2007. Penelitian Tindakan Kelas, Jakarta : Bumi Aksara

Azwar, Saifudin.2000.Tes Prestasi Fungsi dan Pengembangan Pengukuran Prestasi Belajar, Yogyakarta: Pustaka Pelajar Offset

Basrowi dan Suwandi.2008.Prosedur Penelitian Tindakan Kelas. Bogor: Ghalia Indonesia 
Kusnandar.2011. Guru Profesional Implementasi KTSP dan Sukses dalam Sertifikasi Guru. Jakarta: Rajawali Press

Poerwadarminta, W. J. S.. 2006, Kamus Umum Bahasa Indonesia, Jakarta: Balai Pustaka. PP Nomor 55 Tahun 2007

Sudjana, Nana.1991.Penilaian Hasil Proses Belajar Mengajar. Bandung: Remaja Rosdakarya 